\title{
La discreción o el arte de desaparecer *
}

\author{
Pierre Zaoui \\ Traducción del francés al español de Luis Alfonso Paláu-Castaño \\ Universidad Nacional de Colombia, Medellín, Colombia \\ lapalau@gmail.com
}

Para Lise Wajeman y Sacha Zilberfarb

maestros ocultos

Introducción

Cuando uno está invitado en el mundo, es claro que se atraviesa tranquilamente el umbral, que uno sube la escalera, y casi sin darse cuenta de ello puesto que está completamente hundido en sus pensamientos. Es solamente así que se actúa como es preciso hacerlo a su propio respecto y con respecto al mundo.

(Kafka, Diario, 19 de febrero de 1911)

\begin{abstract}
Abrid un día suavemente la puerta de la habitación de vuestros hijos. Los encontráis en el fondo de la pieza, jugando por una vez sin tropeles entre ellos, lejos del sostén y del juicio de los adultos, quizás libres, tal vez alienados, qué importa. Si no tenéis hijos, tratad de sorprender a vuestro amante o a vuestra amante cuando se está durmiendo, es un poco lo mismo. Pues, en los dos casos, qué goce profundo. Ellos no se dan cuenta de tu presencia, no se sienten observados, gozan consigo mismos, dedicados enteramente a la inmanencia de su juego o de su sueño. Si de repente lo aperciben, entonces todo está perdido, pues todo regresará en un periquete en el circo ordinario de la vanidad de los egos, de la rivalidad de las miradas, de la dialéctica mediocre del reconocimiento o de la seducción. Pero mientras no pase esto, algo extraordinario se gana: un momento de amor sin recompensa, no necesariamente muy intenso, pero de una serenidad incomparable.
\end{abstract}

Cómo citar: Zaoui, P. (2020). La discreción o el arte de desaparecer. Ciencias Sociales y Educación, 9(17), 311-338. https://doi.org/10.22395/csye.v9n17a15

Traducción realizada por Luis Alfonso Paláu-Castaño. Agradecemos a la editorial Autrement por permitir el acceso del libro en francés para su versión, en partes, en español. Se conserva la versión editorial en francés. Nota del editor.

Recibido: 10 de febrero de 2020.

Aprobado: 16 de marzo de 2020. 
¿Qué es lo que se siente en primer lugar? No querríamos que eso durara eternamente, a tal punto el placer de la discreción solo vale por fuera de todo sentimiento de eternidad, incluso esta es una de las condiciones sine qua non de su posibilidad. Gozar discretamente de la presencia o de la existencia de los otros, es decir, literalmente disfrutar de manera separada, poseer su aparición sin que uno mismo tenga que aparecer y sostener una postura... necesita, en efecto, inscribirse en una corta duración o incluso más exactamente: en un suspenso del tiempo en tanto que momento separado del orden temporal ordinario donde cada instante sucede a uno de antes y precede a uno de después, y con la condición de no prolongarse más allá de un cierto límite. Porque no exageremos: ver jugar eternamente a sus hijos en secreto no es para nada un ideal del yo, ni para sí, ni para ellos. Y de forma más general no es soportable desaparecer durante mucho tiempo si no queremos que esos placeres furtivos se transformen en desistimiento o en perversión.

Acá reside, en todo caso, la primera especificidad de la experiencia de la discreción; es la experiencia de un tiempo modesto que es suficiente a sí mismo. En efecto, ordinariamente el tiempo concedido a una experiencia nunca le es adecuado, ya sea porque a uno le gustaría que durara más o porque tendríamos ganas de que pasara pronto. Por el contrario, el tiempo de la discreción es un tiempo casi siempre perfecto: tiempo efímero y alegría de que sea efímero.

Pero vayamos un poco más lejos. Abrid otra puerta, esta vez la de vuestro salón. Habéis recibido amigos a cenar y, a vuestro regreso (luego de haber ido a busca no sé qué a la cocina), la discusión se ha acalorado un tanto. Nadie se da cuenta de su presencia y Ud. se desliza subrepticiamente en su asiento. De repente Ud. siente una tranquilidad considerable; se encuentra liberado de las leyes de bronce de la hospitalidad en sus formas más exigentes -acoger al extranjero y ponerle cuidado-como en sus formas más irrisorias — cuidar de que "todo transcurra bien" - o las más narcisistas — mostrar que Ud. sabe recibir y rebozar de espíritu para divertir la concurrencia- No es un asunto que de repente se haya vuelto un bárbaro o un misántropo, es incluso muy exactamente todo lo contrario: liberado de los deberes de hospitalidad, Ud. puede contemplar a los otros con calma y los encontráis bellos, divertidos, profundos, tan singulares. iCómo se embellece y se profundiza al otro desde que uno se encuentra libre de toda deuda a su respecto! Experiencia sorprendentemente contraintuitiva. Intuitivamente uno se imagina, en efecto, que los que desaparecen lo hacen por odio a las apariencias, que los que se retiran del mundo lo hacen por desprecio del mundo. Pero acá todo está al revés y el goce de ya no estar se vuelve el síntoma de un profundísimo amor por el mundo y sus apariencias. Sin duda, es un asunto de perspectiva; mientras que Ud. permanezca cerca de Ud. mismo como cerca de las necesidades de los otros, y en la anticipación constante de 
sus miradas y sus expectativas, Ud. no va a saberlo ver ni escucharlo; por el contrario, desde que ya no hay uno mismo ni el otro, la perspectiva se amplía y el mundo aparece deliciosamente múltiple, descentrado, lejano, recorrido por mil líneas de fuga que se escapan hacia el infinito.

¿Qué es lo que sucede entonces? Su discreta posición, desapercibida, transparente... os conduce a una experiencia nueva: el despojo de vuestros fantasmas de omnipotencia, de ser indispensable, de ser responsable de todos y de cada uno ${ }^{1}$. Hacerse súbitamente discreto es abdicar por un momento de toda voluntad de potencia. No porque la voluntad de poder sea mala en sí misma, sino porque conocemos demasiado bien su cara oscura y tiránica, e incluso a veces su cara luminosa es un fardo penoso en su exigencia de estarse sobreponiendo sin cesar, de llevar sus fuerzas hasta el final de lo que pueden permanentemente. Por eso el goce tan apacible de poder por un instante descargarse sobre los otros o sobre las cosas, de dejarlos aparecer, de no hacerles sombra, de no interponérsele al sol. O más precisamente, la entrada en discreción no es la experiencia de un mundo sin voluntad de poder —-sueño angélico y un tanto hueco-, sino la experiencia de su despersonalización; ya no es su voluntad de potencia la que importa, ni siquiera la de un fulano o de un zutano, sino la voluntad de poder, la que circula entre los seres, los conecta y les hace crear a cada instante gestos, frases, obras que no se olvidan o que se olvidan, pues a veces es aún mejor.

En este sentido, la experiencia de la discreción no es para nada la experiencia de la admiración o de la fascinación, puesto que no hay tanto transferencia de su voluntad sobre la de los otros como un suspenso de nuestra atribución espontánea de la voluntad a figuras personales. No se trata ya de las "almas de fuego" o de las "almas sin reposo", para retomar expresiones stendhalianas, qué importan... sino de las realidades prepersonales y preindividuales; gestos, sonrisas, relaciones calladas, silencios que se deslizan bajo las palabras. $\mathrm{O}$ dicho de otro modo: se sale por fin de ese juego de proyecciones y de introyecciones perpetuas que nos ligan ordinariamente a los otros. La mayor parte del tiempo, uno se dice en efecto "lo amo" o "lo odio", pero en el fondo es siempre la misma empresa de tragar con ansia o de disolver; nos encantaría que él fuera como nosotros, o ser como él. Por el contrario, en la discreción, lo que se ama súbitamente no es ni aún uno mismo, ni ya al otro, sino algo a la vez evanescente y muy preciso, una voluta de humo o una mueca dubitativa que no le pertenece a

En un bello libro reciente, Il y a des dieux, Frédérique Ildefonse (2012) ve en los rituales politeístas de ayer (entre los griegos) y de hoy (en Salvador de Bahía o en Guinea) la experiencia misma de esa "deposición de su omnipotencia" y del tranquilizador suspenso de la cuestión del sentido. No estamos absolutamente seguros de que los antiguos hayan conocido las formas más conspicuas de la discreción. Por el contrario, nos parece decisiva la idea de que un tal desposeerse de omnipotencia esté mucho más cerca de un fenómeno político y religioso que de una postura existencialista siempre frecuentada por la esperanza de salvaguardar una potencia y un sentido en el corazón de la finitud y del nihilismo. Volveremos sobre el asunto. 
nadie. Acá reside sin duda el segundo rasgo de esta experiencia tan singular; un modesto desplazamiento ontológico, pero decisivo en el tiempo en el que opera; desplazar subrepticiamente seres y cosas hacia las relaciones que ellos producen. De alguna manera un nuevo amor de las apariencias sin que haya nada por debajo de ellas que aparecen.

Demos un paso más. Abrid una última puerta, la puerta de entrada, y salid a hundiros en la muchedumbre anónima de las grandes ciudades. Dejáis súbitamente de ser este o aquella, vuestras cualidades públicas se borran, entregáis a la masa indistinta vuestra individualidad, vuestra singularidad, vuestra particularidad. Baudelaire (2010) ha descrito magníficamente este goce del vagabundeo anónimo en el corazón de las metrópolis modernas ${ }^{2}$. Torciendo un tantico el sentido de un cuento de Poe, El hombre de las muchedumbres, él ha hecho un himno a la belleza de las multitudes que solo "el artista de las masas" sabe percibir; conjunto de rasgos sin rostro y de posturas singulares sin individualidad particular para sostenerlos. Incluso se podría decir que es el exacto reverso (pero demasiado poco notado) de aquella palabrota que es "el individualismo" moderno; al deseo de ser reconocido como individuo libre le haría juego el deseo de ya no ser reconocido, de desaparecer en la multitud. Dicho de otro modo, nuestra modernidad no se caracterizaría solamente por una lucha desenfrenada por el reconocimiento y la visibilidad, sino también por una lucha subterránea, más calmada pero igualmente tenaz, por el anonimato y la invisibilidad. Al sueño warholiano de fifteen minutes of fame ofrecidos a cada uno por la democratización mediática, le respondería el sueño anónimo y múltiplemente compartido de fifteen minutes of vanishing, quince minutos de desaparición ofrecidos a todos por la masificación y la anonimización de las sociedades modernas. Sin duda, no se trata de dos sueños contradictorios, sino más bien de dos caras de una misma época: sería en los mismos espíritus que al veneno de la vanidad y del egocentrismo respondería el contraveneno de la discreción; Baudelaire y Warhol están ahí como testigos.

Desde este punto de vista, se toca la dimensión paradójicamente política de la discreción. Pues no solamente se juega aquí una cuestión bajo ciertos respectos un poco obsoleta de tacto, de atención al otro, de respeto de las conveniencias, sino ante todo una cuestión de resistencia a un nuevo orden establecido; el que pretende identificar el ser y el aparecer y el valor de la visibilidad. Ciertamente, una vez más, el amor del aparecer no es nuevo y no es necesariamente malo; los griegos de antes de Platón habían incluso inventado un magnífico culto de las apariencias sin profundidad, sin trasfondo, sin trascendencia: pura belleza sin otra justificación que ella misma. Pero lo que ha cambiado es que ese mundo de las apariencias se ha refractado en un juego de imágenes de sí sin belleza

Mirar en particular los capítulos 3 y 4 de este autor. 
y con una profundidad infinita. Los héroes antiguos y clásicos no eran proyecciones de uno mismo y dejaban en el fondo sin vigilancia la vida ordinaria. Los héroes modernos encarnan, ora los fantasmas de omnipotencia del que solo sueña en aparecer, ora la huida paranoica del que no puede ya soportar ser visto en un mundo que no conoce sombra, ocultamiento ni territorio no vigilado. Por esto el envite político y actual de la discreción; aprender a abandonar el orden de la mostración de sí y de la vigilancia generalizada es ya entrar en una cierta forma de disidencia. De manera más general, toda resistencia seria y modesta ha comenzado siempre por la aceptación de una cierta clandestinidad, es decir, el arte de arrasar los muros y de no hacerse notar, el arte de la discreción.

Llegamos aquí a un tercer rasgo de la discreción, tan contraintuitivo como el precedente: el de abrir, bajo su apariencia plácida, retirada, apolítica, a una relación nueva con la política. Esta última, ciertamente, no anula las formas políticas tradicionales, no hace caso omiso de las declaraciones públicas, de los efectos de tribuna y de publicidad, de los banquetes y de las revueltas comunes, de los honores y de las recompensas, puesto que supone, por el contrario, que hay un mundo político del que puede alejarse o en el que pueda desaparecer un momento. Pero él le añade una dimensión suplementaria o las duplica clandestinamente. Aprender a hacerse imperceptible o gozar de desaparecer no es una alternativa a la política tradicional, sino que es quizás el único medio para llegar a soportarla.

Tomemos solamente un ejemplo, el de la manifestación política. A primera vista, es lo contrario de toda discreción; se trata de exponerse, de mostrar y de demostrar su fuerza (demostration, se dice en inglés). Más aún, la psicología de las muchedumbres, en Le Bon o en Freud, siempre ha querido ver en las manifestaciones políticas el signo de una fusión con el jefe carismático, regresión identificadora a partir de un "rasgo unario" que esta última encarna, es decir, un rasgo común que hace posible a la vez la identificación fusional de individuos distintos y la descarga afectiva colectiva. Dicho de otra manera, el individuo no desaparecería en la masa agitada más que para reaparecer en la persona gloriosa del Duce o del Führer. Sin embargo, ¿estamos seguros de que toda manifestación tiene que reducirse a un tal modelo en el fondo fascista o populista? Si miramos con más detenimientos, parece más bien que el encanto de muchas manifestaciones es precisamente no mostrar o demostrar cualquier cosa ni disolverse en la persona de un jefe, sino gozar de una anonimización de todos que, lejos de borrar, está subrayando la singularidad de cada uno. En una manifestación alegre, uno se burla de los líderes o de los "delegados" que van adelante, que nunca vemos, porque en ella entramos y salimos cuando nos dé la gana, se aparece de repente en una sonrisa furtiva intercambiada con un 
desconocido para desaparecer inmediatamente luego; en una palabra: uno ama volverse invisible en el lugar mismo de su manifestación sin tener que ocultarse.

Sin embargo, tales experiencias se las experimenta mucho más de lo que se las comprende. Son experiencias extremadamente ordinarias, pero tan nimbadas de misterios y de paradojas contraintuitivas que comienzan por dejarlo a uno sin voz. Existe, sin embargo, un escritor que ha llegado bien lejos en la tentativa no solamente de vivirlas sino de pensarlas. Es Kafka. Tratemos de escucharlo un instante.

\section{La experiencia de Kafka}

"En tu combate con el mundo, secunda al mundo". Cuando Kafka anota esto en su Diario el 8 de diciembre de 1917, parece querer expresar al menos dos cosas. Primero, sin duda, una incapacidad de estar en el mundo inocentemente que lo condena a tener que batirse sin cesar para encontrar la buena distancia con los seres y las cosas que están afuera; ni demasiado cerca para no ser devorado (es por esto por lo que hay que combatirlo), ni demasiado lejos para no sentirse demasiado solo y abandonado (es por esto por lo que hay que secundarlo). Pero bajo una tal postura desesperada (o existencialista antes de tiempo) también está diciendo otra cosa, casi su contrario, que lo peor en un tal combate no es que el mundo nos violente y nos quiebre, sino más bien que uno logra por las buenas someterse al mundo, que no hay más que un sí mismo personal totalmente autocentrado, es decir, inmundo en el sentido propio, desprovisto de mundo, y que un tal sí mismo se siente triunfante o miserable. Por esto siempre es necesario "secundar el mundo", es decir, no solamente dejar de querer a cualquier precio existir a sus expensas, sino sobre todo de ayudarlo a ser él mimo, a aparecer, a vivir. Como si el día en que no hubiera ya nadie para pensar y tener en consideración las cosas y los seres, ellos dejaran de existir, con la condición de escuchar en este "como si" toda la modestia y la sutileza kafkianas. Pues exigir que secundemos el mundo es todo lo contrario de creer que el mundo no giraría sin nosotros; es alegrarse de que el mundo gire efectivamente sin nosotros, aunque puede ser que un día deje de girar si ya no hay nadie para alegrarse de su autonomía; triple brecha decisiva entre una creencia y un regocijo, entre un condicional y un indicativo, entre un sí pleno de él mismo y un sí impersonal, el sí de un cualquiera, ni siquiera el de Kafka, sino de Joseph $\mathrm{K}$, o simplemente $\mathrm{K}$. El inmaterialismo de Kafka, es decir, la idea de que cualquier cosa, toda sensación, solo existe porque ella es percibida por un espíritu invisible, no es un monumento de pretensión, sino de modestia discreta. En una frase, Kafka parece condensar de la forma más precisa el problema, la modernidad y el verdadero camino de la discreción. El problema de la discreción es su equivocidad aparentemente extrema. Como el ser en Aristóteles, la discreción 
se diría irrevocablemente en muchos sentidos. Equivocidad primero en el plano moral, puesto que es el primer dominio en que parece surgir su idea; por un lado, saber ser discreto, es decir, saber no hacerse notar mucho y borrarse ante los otros es uno de los principios fundamentales de toda buena educación; por el otro lado, es con frecuencia una buenísima escuela para producir renunciantes avergonzados de ellos mismos, cobardes, almas serviles. Pero equivocidad también en el plano político-jurídico: por un lado, la discreción tiene que ver con el derecho privado (respetar la discreción del otro es respetar el libre uso que él tiene de sus propiedades); por el otro lado, la discreción sigue siendo políticamente de un puro uso público (¿para qué sirve ser discreto cuando se está absolutamente solo?). Equivocidad finalmente, y más profundamente, en el plano casi ontológico, puesto que hacerse discreto es a la vez salir del juego de las apariencias y prestarle por fin atención, retirarse del mundo y dejarlo ser (Let it be). La discreción solo les retira todo el ser a las apariencias para restituírselo por entero. Equivocidad, finalmente, del afecto pues la discreción es tanto un afecto como un comportamiento; por un lado, es un sufrimiento ser tan discreto, casi un desespero; y por el otro, es una alegría y una paz en el corazón mismo de una batalla perpetua.

La modernidad de la discreción es menos evidente. ¿No aparece ella espontáneamente como una virtud un tanto anticuada, propia de las sociedades de corte y de parolas de alcoba, pero profundamente inadaptada a nuestra civilización de la imagen y de la publicidad? Sin embargo, las palabras de Kafka desmienten frontalmente este prejuicio que se ha vuelto corriente. La discreción se volvería precisamente la virtud más preciosa en nuestras sociedades modernas, amenazadas sin cesar por el panóptico totalitario: en el pasado, el de la prisión benthamiana donde cada detenido podía ser visto por un guardia situado en su centro; en la actualidad, el del registro generalizado de las cámaras de vigilancia, el de las chuzadas telefónicas, el espionaje del correo electrónico, de drones y de satélites para el pueblo, de paparazzi y de dosieres comprometedores para las celebridades. Además, quizás los historiadores podrían un día confirmar que las sociedades de antiguo régimen eran todo menos sociedades de discreción, salvo las del secreto de Estado. Del pueblito a la Corte, caía una cascada de pequeñas comunidades cerradas donde cada uno espiaba a todos los otros y donde lo esencial era hacerse ver por el rey o por el cura del pueblo, mientras que nuestras sociedades modernas nos habrían aportado, no solamente la publicidad, sino también su anverso, el anonimato impersonal, el goce de no contar para nada desde que se tenga la fuerza de no jugar el juego. No sabemos todavía. Filosóficamente, se puede, sin embargo, remarcar ya esto para seguir a Kafka; pueden perfectamente multiplicarse las emisiones de telerrealidad, las microaceras, las ruedas de la fortuna... una sociedad de masas seguirá siendo siempre una sociedad de masas, es decir, una sociedad en la que la multitud está 
llamada a seguir siendo discreta, así lo quiera o no, y cualquiera sea el régimen político en vigor. Dicho de otro modo, bien puede determinarse la modernidad como el surgimiento del pueblo en la escena política, artística, literaria... siempre será un trampantojo; en verdad, el pueblo nunca surge, nunca se representa, es el gran discreto, eternamente minoritario, eternamente inaudible, incluso cuando manifiesta y se revuelta. La paradoja de la noción misma de popularidad es su signo más claro; solo es popular lo que ha abandonado para siempre al pueblo.

Toda la cuestión que se plantea en el plano moral y político es que una tal caracterización de pueblo, de los seres cualesquiera, no está lejos de la infamia; ¿no será esto condenarlos a seguir siendo siempre inaudibles, invisibles, sometidos? Y no lejos de la falsedad; ¿acaso no son, por el contrario, los aristócratas los que predican los encantos de la discreción contra la vulgaridad bulliciosa y ávida de reconocimiento del pueblo? Estamos perdidos. Pero también aquí Kafka nos abre una vía, quizás incluso la vía del "verdadero camino", para retomar sus palabras. Pues él dice: ser o no discreto no es ni un bien ni un mal, no importa, lo que importa es secundar el mundo, es decir, aceptar por una parte no ser el primero, no estar en el centro ni ser el origen, y por otra parte sostener lo que es, ponerse al servicio, no de sí — tripa, quimera o mentira - ni del otro - tirano o fantasma - , sino de cada cosa, cada ser, cada instante. Dicho de otra forma: Kafka abre una vía para tratar de pensar la discreción, ya no como virtud, cualidad o signo de buena educación un poco rancia, sino como experiencia profundamente moderna y trabajando todavía para lo peor y para lo mejor. La discreción sería esto: ya no una virtud, una forma permanente del carácter, sino una experiencia rara, ambigua y, sin embargo, infinitamente preciosa.

Tratemos de explicitar esta vía inédita, de proseguir esta voz tan singular.

\section{Una experiencia tan común como escasa y difícil}

Abrir las puertas que conducen a lo invisible o más exactamente a lo inaparente, es abrirse a una experiencia tan preciosa como escasa y difícil. Todo el problema consiste, sin embargo, en comprender por qué, si una tal experiencia se presenta tan preciosa, es necesario conceder al mismo tiempo que es rara y difícil. Se comprende que Spinoza cuando habla de la beatitud o "salvación de los hombres" al final de la Ética, pueda reclamar de la máxima latina "omnia praeclara rara", todo lo que es precioso (o excelente) es escaso ${ }^{3}$. Pero la discreción no tiene una tal pretensión; ella engendra alegrías mucho más modestas en las que no se trata de salvar a nadie, ni a sí mismo, ni a los otros, ni al mundo.

Se trata de la última frase de Ética (quinta parte, proposición 42, escolio). Más exactamente Spinoza se interroga así (en la traducción de Peña): "Y arduo, ciertamente, debe ser lo que tan raramente se encuentra. En efecto: si la salvación estuviera al alcance de la mano y pudiera conseguirse sin gran trabajo, ¿cómo podría suceder que casi todos la desdeñen? Pero todo lo excelso es tan difícil como raro" (Spinoza, 1980, p. 279). 
En función de lo que acabamos de entrever rápidamente, se podría decir que se trata de una experiencia casi inversa a la beatitud. Esta nos permite experimentar que somos eternos, aquella que somos mortales y que es una buena cosa; esta nos promete una potencia máxima "en tanto que está en nosotros", dice Spinoza, aquella, por el contrario, no nos permite terminar con ello, sino suspender por un tiempo nuestros deseos de potencia y de encontrar precisamente nuestro goce en una tal suspensión; esta nos libera radicalmente del orden de los afectos propiamente políticos (el temor, la esperanza, la piedad, el odio, la indignación, el menosprecio...), aquella se constituye como una política de la disidencia necesariamente nutrida, en parte, de tales afectos, al menos en un modo menor, de cara al mundo aterrador de la visibilidad permanente y de la vigilancia generalizada, es decir, de una buena parte del mundo contemporáneo. Finalmente, digamos que la beatitud, aunque conquistada in fine bajo forma intuitiva, solo se presenta verdaderamente al final de un largo esfuerzo que exige aprender previamente matemáticas, la existencia necesaria de Dios, los principios físicos del mundo, las maquinaciones de nuestros afectos y las formas de nuestra servidumbre nativa (lo que, reconozcámoslo, no es mayor cosa), mientras que la de la discreción parece a la mano de cualquier hijo de vecino y de manera resueltamente inmediata, desde el primer "género de conocimiento", diría Spinoza, es decir, desde la infancia, como cuando uno podía echarse un sueñito discreta y deliciosamente en el fondo de la clase porque el maestro había escogido a otro para que pasara al tablero.

Pero entonces, ¿por qué, a pesar de todo, constituye una experiencia casi tan rara y difícil como la de la beatitud? Evidentemente, encontramos primero toda la serie de razones políticas ya evocadas: ¿cómo lograr llegar a ser discreto en sociedades en las que casi todo, desde el mundo de la empresa al mundo del arte, pasando por la televisión y las redes sociales, nos recuerda que ser es exclusivamente ser percibido? Pero tales razones siguen siendo insuficientes, pues todavía nos falta mucho para vivir en puras sociedades del espectáculo; se podría incluso llegar a apostar que, a pesar de todos los esfuerzos de los que se aprovechan de un sistema tal, los drogados de la imagen y del deseo de aparecer a cualquier precio, siguen siendo ampliamente minoritarios. Pues la televisión y las redes sociales son un poco como la música de ascensor: puede que estén encendidas, pero eso no quiere decir que la gente las mire; no será por comunicarse por Facebook que unos se interesan en los otros.

En desquite, existe una razón en un sentido mucho más simple, pero también más radical que explica quizás mejor una tal dificultad; el hecho de que una tal experiencia es a priori muy poco deseable. O más precisamente: parece como embrujada, en todo caso amenazada a cada momento de convertirse en su contraria. ¿Desaparecer es una paz inesperada? Pero, de repente, se mezcla 
aquí la angustia de no tener sino un comportamiento regresivo y perverso, el de reanudar con el goce avergonzado de mirar por los huecos de la cerradura hasta hacer del mundo entero un vasto peep-show (to peep, en inglés, quiere decir "ver a través de una mirilla"). Tras esta angustia surge una segunda forma de ella, más profunda, propia de toda neurosis obsesiva: la angustia de castración que se caracteriza especialmente —como dice Freud- por un "desistimiento en beneficio del padre", es decir, la angustia de que nuestra delicadeza discreta no sea sino la pantalla de una cobardía más original. Y bajo esta segunda angustia neurótica, un tercer tipo puede asomar todavía, la peor de todas, al borde la psicosis: la de desaparecer para siempre, no ser ya nada, morir, es decir, la angustia de solo ver ya, bajo nuestros retiros y nuestros desataduras más refinados aparentemente, el oscuro trabajo de la pulsión de muerte que nos enseña tristemente a gozar sin límite de nuestras propias abdicaciones y derrumbamientos, a gozar de devenir un desecho que ya nadie ve.

¿Descargar su omnipotencia es aún un beneficio? Pero de repente uno siente que vuelve aparecer su terrible timidez de niño y su cortejo de vergüenzas, de intenciones incumplidas, de sufrimientos. Y entonces surge la sospecha completamente nietzscheana de las razones ocultas de su discreción. En efecto, aunque Nietzsche era adepto a las máscaras, a las disimulaciones y a los retiros inactuales, no dejó de manifestar sus más grandes dudas sobre ese turbio deseo de querer la nada, por no decir de no querer ya nada del totazo que ha podido afectar a las más altas culturas, el politeísmo griego, el judaísmo, el cristianismo, el islam, el budismo, el nihilismo contemporáneo. Inmensa ambigüedad. Por un lado, un tal deseo parece nutrir las posturas más espléndidas. La del pensamiento trágico de los griegos que se resume, en un sentido, en la reprobación del horror y de la injusticia de la vida; mê phynaï gritan los héroes y los poetas griegos, eso que Nietzsche va a llamar "la antigua sabiduría de Silene". Mê phynaï, literalmente, "mejor no haber nacido", mejor desaparecer, es el grito que lanza Edipo al final de Edipo Rey, y el grito en que estalla Antígona cuando se encuentra enterrada viva; es el grito de todos los héroes trágicos que, frente al horror de la vida, no quieren que ella cuente para ellos, y consideran como bueno su negativa a someterse a los decretos del destino o de la ciudad, incluso aunque pierdan las razones mismas de vivir. Es todavía la misma la que nutre lo que Nietzsche llama el "gran estilo en la moral" que habrían inventado los judíos planteando aquella extraña exigencia de someter siempre su voluntad egoísta a las exigencias del otro. Y es también la que habita a Sócrates, Platón y los primeros cristianos en su exigencia irrazonable de verdad absoluta y total, que está en la fuente misma de toda la ciencia moderna. Siempre es esta la que nutre lo que Nietzsche llama el "nihilismo extático" en la fuente misma de la advenida del superhombre. Pero por el otro lado, un tal deseo de retiro y de discreción, de no aparecer más, de disolver su voluntad en la de los 
otros, es igualmente un terrible error. Es el que nutre el pesimismo patológico de Schopenhauer y del Nietzsche de juventud. Es el que nutre el resentimiento de los judíos y la mala conciencia de los cristianos. Es el que, mucho antes de cualquier esperanza de nihilismo extático, nutre a los nihilismos reactivo y pasivo, es decir, los deseos de destruirlo todo, luego de no volver a hacer nada ni quererlo, que son los flagelos de nuestra modernidad. En una palabra, es imposible interpretar unívocamente nuestros deseos y nuestras experiencias de discreción, y uno nunca sabe por adelantado si uno se eleva y revivifica o si uno se está deshaciendo y se mortifica.

En fin, ciertamente, no hay política seria sin secreto ni disimulo, sin ser un poco "zorro" diría Maquiavelo; más aún, una política de la discreción y del anonimato constituye, sin duda, como en el caso de las manifestaciones pacíficas, la forma suprema de la democracia por fin liberada de todo salvador supremo, de todo Dios, de todo César, de todo tribuno. Pero los "secretos de Estado" y los poderes llamados precisamente discrecionales, es decir, sin control y enteramente sometidos a la buena voluntad secreta de un soberano invisible y policial, son, por lo mismo, los más seguros sepultureros. Se cree hacer prueba de espíritu loando el secreto, la disimulación, la máscara, jugando el juego del poder porque "todos los hombres son bribones", y descubrimos súbitamente con escalofrío que uno se ha vuelto un pequeño Maquiavelo de provincia a las órdenes de un alcalde imbécil e infame, a la manera del Lucien Leuwen de Stendhal en la novela epónima.

Un tal embrujo de la experiencia de la discreción o una tal inversión del pro en contra, se percibe claramente en el otro, y tanto más cuanto que, en los otros, uno aprecia espontáneamente su discreción, su ausencia de intrusión, su tacto, y uno está espontáneamente inclinado a solo ver una virtud... sin doble cara. ¿Qué es lo que nos impide con una tal seguridad ingenua no ver allí un gran poder de disimulo, una perfecta hipocresía, una forma particularmente refinada de narcisismo o de simple vileza? Proust describe una escena ejemplar de ese tipo en $A$ la sombra de las muchachas en flor. Cuando el narrador se enamora de Albertina, se lo confía a Andrea su mejor amiga, de la que aprecia particularmente su tacto y su delicadeza (ella nunca le habría contado nada que se dijera de él y que lo hubiera podido ofender). Y un buen día descubre que Andrea era también discreta con Albertina, pero en el otro sentido: Andrea nunca le contaba a Albertina las gentilezas que el narrador le confiaba con el objetivo secreto de que se las hiciera saber. Es lógica toda la simpatía que le tenía el narrador y entonces concluye: "Albertina hubiese sido incapaz de los mil refinamientos de bondad que tenía Andrea, y, sin embargo, no estaba yo tan seguro de la bondad de la segunda como lo estuve luego de la bondad de Albertina" (Proust, 1954, p. 922). Con las almas plenas de tacto y de discreción, uno puede estar 
seguro de que nunca lo ofenderán, pero tampoco se podrá estar seguro de ser sinceramente amado, ayudado, comprendido.

Pero por adelantado nos debemos prevenir, pues el encanto singular de la experiencia de la discreción puede ser un refugio que solo sirva de ocultamiserias o de racionalización (en el sentido psicoanalítico) de los peores afectos: la vergüenza, la cobardía, la pereza, la abulia, la duplicidad, la tiranía. Pero toda la apuesta que hacemos consiste precisamente en probar que esas formas de invertir la experiencia maravillosa de la discreción en su contraria no son inevitables, que puede existir un arte de la discreción capaz de desembrujarla, sino completamente, por lo menos mucho, para devolverle al menos en parte su inocencia, su modestia y más aún su intermitencia, es decir, su advenida imprevista y fugaz.

Más precisamente, parece que un tal arte exige al menos un triple gesto. Primero, el de historizar y politizar la experiencia de la discreción. Esta no vale en todo tiempo y en todo lugar. Existen, por el contrario, momentos históricos, macrohistóricos y microhistóricos, como lugares geográficos y sociales, donde toda la vida pasa por el lado de la manifestación, de la aparición, de la capacidad de no retirarse y de hacerse escuchar y notar. Por esto su dimensión es primordialmente política, micropolítica sin duda, pero sin dejar de cuestionar la totalidad sistémica de nuestra modernidad biface. Cuando la discreción no pasa de ser una cuestión de buena educación y de conveniencia, de cortesía y de buenas costumbres, o incluso simplemente de existencia individual, ya no estamos en una experiencia viviente, sino en un encorsetamiento y una falsedad. Pues lo que la hace viva es precisamente siempre el medio y el juego de plazas en las que surge. En particular, cuando son siempre los mismos los que se revelan discretos y los que hacen que se hable de ellos, ya no podrá haber allí experiencia nueva, imprevista, precisamente lúdica, sino solamente lo que Jacques Rancière (2014) llama "el reparto de lo sensible", es decir, la repartición fijada de las plazas y de las visibilidades que siempre se opera por exclusión de una parte de la población — los "sin parte", los "invisibles" que son aquellos que no pueden escoger la invisibilidad porque precisamente les toca sufrirla-. Dicho de otro modo, la discreción no puede reducirse a una simple cuestión de saberse comportar o de justa reserva privada ni a un goce reservado a las almas públicas que de vez en cuando tendrían un claro derecho a regocijarse en el (re) descubrimiento de que los otros existen. Es, por el contrario, una experiencia política paradójica que concierne a todo el mundo, aunque no le acontezca más que a algunos o de manera micropolítica ver alegremente cómo se desplazan las posiciones, las voces, las atenciones, al mismo tiempo que se reconoce que el único que puede operar un tal desplazamiento es aquel al que ordinariamente no se lo ve, al tímido, al anónimo, al sin apellidos, sin sitio, sin títulos. 
Segundo, para que la discreción pueda pensarse como un arte, es decir, como algo que nunca sea simplemente un rasgo idiosincrático, sino una capacidad que se adquiere, se nutre, se defiende, hay que desembarazarse en la medida de lo posible de toda psicología, o de toda consideración de la discreción en términos de rasgo de carácter. La apología de la discreción no es y no puede ser una apología de las almas discretas por, al menos, dos razones casi evidentes. Primero, porque las almas verdaderamente discretas no tienen ninguna necesidad de un tal arte, por no decir que tendrían, más bien, a veces necesidad de un arte contrario: el que consiste en aprender a mostrarse, a afirmarse, a protegerse del deseo patológico de desistirse. Segundo, y más profundamente, porque la idea misma de una discreción continua constituye casi una contradicción en los términos. En efecto, en su sentido etimológico, "discreción" viene del latín discretio que significa discernimiento, separación, distinción, lo que se entiende aún en el inglés discretion y lo que le ha dado su sentido matemático de discontinuo. No podríamos, por tanto, ser discretos continuamente; la discreción misma presupone una dialéctica más sutil de la aparición y de la desaparición, de la mostración y de la reserva. Es en este sentido, en todo caso, que el arte de la discreción nos parece tener que ver con un gesto verdaderamente metafísico, por no decir inicialmente teológico, ese que busca constituir su concepto distinguiéndolo de experiencias cercanas pero distintas; aquellas antiguas y mundanas del tacto, el pudor, la compostura, la cortesía, y las religiosas de la humildad, el desprendimiento o el retiro del mundo.

Tercero, una vez planteadas estas condiciones de posibilidad de un arte de la discreción entendido como arte de desaparecer, quedan aún por detallar los rasgos particulares y prácticos. ¿Cómo, concretamente, llegar a asumir la dimensión primordialmente política de la discreción sin contravenir los principios mismos de toda democracia: publicidad de las opiniones y transparencia en las decisiones? ¿Cómo, concretamente, preservar los sentidos etimológico y matemático de lo discreto sin contentarse con estar jugando a una polisemia un tanto fácil? ¿Cómo, concretamente, preservar la experiencia luminosa de la discreción, de los dos abismos patológicos que la bordean, por un lado, la disolución hemorrágica del ego, y por el otro el encerramiento narcisístico? ¿Cómo, concretamente, hacer del deseo de su propia desaparición otra cosa distinta a una pasión sacrificial, incomprensible o mórbida? Para responder a tales preguntas, el gesto de constitución de un arte de la discreción está llamado necesariamente a desagregarse en una miríada de gestos tenidos, en parte contradictorios, en parte no articulables. Es por esto por lo que solo se trata de un arte y no de una ciencia. Es por esto por lo que la mayor parte de los grandes pensadores de la discreción o de la desaparición se han expresado esencialmente por medio de aforismos y fragmentos. Bajo los grandes gestos de constitución de nuestros ideales políticos, morales, artísticos, la discreción trabaja para fragmentar, 
desagregar, cavar huecos y madrigueras para airear un poco y permitir la libre circulación de los roles, de las formas y de las fortunas.

Tenemos que continuar, desplegar más lentamente y más históricamente estos tres gestos, interrogar las condiciones de emergencia de la discreción. Interrogar, por medio de una genealogía un tanto salvaje, las experiencias que han permitido, al menos en Occidente, acceder a una tal experiencia. Interrogar la ambigüedad profunda de la naturaleza política de la discreción, para terminar interrogando en orden más disperso las formas concretas por las que se puede aprender a entrar en discreción, no como se entra en religión o al convento, sino como se entra furtivamente en las casas de gentes que uno no conoce, no por curiosidad y por fractura, sino simplemente para ver cómo viven ellos y dejarse emocionar por la belleza neutra de las cosas, es decir, sin sujeto personal y sin objeto específico.

\section{La discreción: ivirtud inmemorial, griega 0 aristocrática?}

¿De dónde me viene esta seguridad repentina? iPodrá durar! Podré así entrar y salir por todas las puertas, como ser humano que se mantiene más o menos erguido.

Pero yo no sé si esto es lo que quiero.

(Kafka, Diario, 6 de noviembre de 1913)

Ser discreto, es decir, no hacerse notar, saber callarse y hacerse invisible, salir de avance o, al menos por momentos, del juego de gallos de la mostración y del reconocimiento, es algo que en apariencia tiene que ver con una simple virtud moral. No es necesariamente una alegría, una experiencia singular y fecunda, sino ante todo un deber que uno debe cumplir para vivir en el mundo plegándose a sus normas, sus superioridades, sus restricciones. ¿Pero de dónde viene entonces una tal moral de la discreción? En un primer análisis, parece hundir sus raíces aún más lejos, en un fondo inmemorial, propio no solamente de la humanidad, sino de la vida entera en tanto que esta sería primordialmente disimulación y mentira, o al menos de la vida de las plantas y de los animales más débiles, "aquellos a quienes les ha sido negado servirse, en la lucha por la existencia, de cuernos, o de la afilada dentadura del animal de rapiña" como dice Nietzsche (s.f., p. 2). Esto parece confirmar el propio lenguaje común. Imaginemos por un instante al hombre en las inmensas selvas del Paleolítico, rodeado de bestias salvajes, ora más peligrosas que él, ora más rápidas; si él no sabe instintivamente hacerse discreto, "avanzar silenciosamente" como un felino, "agazaparse" en madrigueras como los pequeños mamíferos, "fundirse 
con el paisaje" como un camaleón o un fasma ${ }^{4}$, seguro que estaría perdido por adelantado y terminaría bastante pronto devorado, o muerto de hambre. En este sentido, la discreción provendría de nuestra parte más animal, solo sería una forma particular de nuestro instinto de conservación.

Sin embargo, seamos un poco más precisos y miremos de nuevo las junglas hostiles. La vida parece, de hecho, inventar aquí casi por partes iguales, por un lado, las formas más inesperadas de discreción, y por el otro, las formas más variopintas de mostración y de demostración de sí mismos. Por un lado, una multitud de madrigueras, de escondrijos, de sombras furtivas, de silencio; por el otro, un desborde de colores, de formas de gritos, de desfiles. Más aún, incluso los animales más discretos nunca están acá seguros; sus depredadores han terminado también por aprender a desalojarlos, a encontrarlos en sus madrigueras o a esperar pacientemente la más ligera aparición que los perderá. La animalidad es tanto una escuela de la indiscreción como una escuela de la discreción. Y en este sentido, no podríamos ver en ella el fundamento de una experiencia singular de la desaparición que alterna entre los dos, pero que no los confunde nunca. Por el contrario, la animalidad sería un momento de completa confusión en el que discreción e indiscreción se identificarían en el seno de un mismo arte de la adaptación a las circunstancias. No es por nada que cuando Nietzsche describe esas formas originales de la vida, habla de arte de la mentira, de la disimulación, o mejor aún: arte de la máscara, pero no de discreción propiamente hablando. Pues hay dos razones, casi siempre simultáneas, para llevar una máscara: para ocultarse y para mostrarse, para fundirse por debajo o, por el contrario, para poner por delante ciertos rasgos particulares. No es en este terreno donde vamos a tener la suerte de encontrar la invención propiamente de la discreción, salvo que hagamos del carnaval su momento privilegiado de expresión, corriendo el riesgo de ya no saber del todo de qué se está hablando.

Comencemos más bien nuestra averiguación en el terreno de la moral, literalmente de las costumbres, es decir, de las reglas comunes de comportamiento en sociedad más allá de las formas instintivas de disimulación.

\footnotetext{
La categoría fasma no tiene que ver con la palabra fantasma. Para mostrarlo, en consonancia con lo que se plantea en la traducción del texto de Pierre Zaoui, se puede recurrir al libro de Georges Didi-Huberman, Fasmas. Ensayos sobre la aparición 1 (2015). Didi-Huberman dice que el fasma no es un fantasma, sino aquello que se funde con el paisaje, ya que, "cuando me dicen que hay algo que ver y no ves nada, te acercas: te imaginas que lo que hay que ver es un detalle no percibido de tu propio paisaje visual. Ver aparecer los fasmas exigió lo contrario: des-enfocar, distanciarme un poco, dejarme llevar por una visibilidad flotante, eso es lo que tuve que hacer más o menos por casualidad, o con un movimiento que anticipaba el miedo." (Didi-Huberman, 2015, p. 20). El fasma remite al camuflaje donde un viviente, llamase camaleón o mariposa, se mimetiza en el paisaje exigiendo del observador desenfocar su mirada para poder comprender el fenómeno. Nota del editor.
} 


\section{Sobre la discreción inmemorial; la moral de los mitos}

A primera vista, parece difícil encontrar una moral o una cultura tradicional que no predique de una u otra manera la discreción. Sin duda, sus manifestaciones concretas pueden revelarse infinitamente variables histórica y geográficamente; aquí habrá que aprender a no hacer ruido, allá a no levantar los ojos, acá a no oler ni a tocar; allí a no mostrarse en ciertos lugares, más allá a no manifestarse en algunos momentos; aquí a no meternos "en lo que no nos importa", allá lejos a no manifestarnos ni siquiera si eso nos concierne; aquí cubrirse el cuerpo o la cabeza para manifestar su retiro, allá a descubrirse el cuerpo o la cabeza para manifestar su benevolente respeto; acá a prohibirse únicamente ciertas palabras y algunas preguntas, allí prohibirse únicamente ciertos gestos y algunas posturas; aquí contener el cuerpo, allá controlar el vestido, mucho más allá poner mucho cuidado al verbo. Pero cada vez se encontrará la misma invariante forma; ninguna moral parece poderse constituir sin establecer algunas reglas de discreción.

Se lo puede, ante todo, comprender lógicamente. La discreción, cualesquiera sean sus objetos, los sentidos, los lugares y los tiempos en los que se aplica, ¿acaso no consiste originalmente en restringir sus manifestaciones "las propias" para dejarle sitio al otro y al mundo? ¿No es este el sentido primero de toda moral, de toda reglamentación del comportamiento, esto es, aprender a que su yo no es el centro del mundo, y que los otros, con su propio deseo de manifestación, existen y tienen un derecho, ora igual, ora superior pero nunca inferior, a ser y a ocupar la escena de la vida? En este sentido, casi que se podría decir que la discreción constituye quizás el mínimo común denominador de toda moralidad; entrar en el sollen-sein o el ought-to-be, en el deber-ser de la moral, sería primordialmente entrar en el deber de no ser en demasía y recordarse que el otro existe (ya sea Dios, prójimo, semejante, extranjero). Al contrario, el verdadero bárbaro, el nocivilizado por excelencia, no sería el que ignora la distinción entre el bien y el mal - puesto esto le llega ocurrir hasta a los mejores—, tampoco sería el degollador de viudas y de huérfanos — pues se han conocido civilizaciones que no tenían el más mínimo escrúpulo ante tales prácticas-, sino el que se manifiesta un tantico de más, que "chicanea un poquito de más", como se diría hoy.

Se puede luego comprender más simplemente una tal universalidad de la discreción de manera empírica. ¿Acaso no se la encuentra, de hecho, en todas las culturas? Los romanos inventaron el término discretio, que significa ante todo separación y poner en secreto; pero los griegos tenían el aidôs, el pudor o la vergüenza, sobre la que vamos a volver; los judíos tenían la anava (modestia o humildad) y la tsniout (el conjunto de las reglas de pudor); los cristianos la modestia y la humilitas en parte solamente derivada de la anava judía; los musulmanes tienen el harim (el lugar secreto o íntimo), la hichma (el pudor 
o la compostura que regula las relaciones entre las generaciones) y el haya (el respeto o la cortesía). Seguramente que encontraríamos reglas similares en las culturas del Extremo Oriente o en África, en las culturas del mundo entero. ¿No aconsejaba también Confucio "mirarse escrupulosamente uno mismo, pero a los otros verlos solamente con discreción"? Todas las morales parecen estar inclinadas sobre esta necesidad de imponerse, ya sea de manera muy suelta o de forma muy precisa, una separación o una buena distancia, no solamente en las relaciones interhumanas, sino también claramente en las relaciones con Dios o con la naturaleza, sin olvidar las relaciones consigo mismo. La discreción constituiría una especie de invariante antropológica empírica casi comparable a la prohibición del incesto; cada vez las reglas son diferentes, pero cada vez es idéntica la necesidad de imponer una separación entre los seres y entre las cosas, por medio de restricción y disimulación de la subjetividad individual. Sin embargo, esta invariante antropológica conoce, al parecer, una excepción: la civilización occidental moderna. ¿No se constituye esta, en efecto, en torno a la promoción históricamente inédita de la subjetividad, haciendo en el mismo movimiento de la alteridad y de la diferencia un infierno, a la manera del $A$ puerta cerrada de Sartre, donde "el infierno son los otros"? Es uno de los sentidos que se le presta al ataque nietzscheano a la moralidad occidental, y en particular a Rousseau, a semejante "tarántula moral" que habría infectado todo el campo de la conciencia occidental con sus sueños de sinceridad total, de pequeñas comunidades transparentes, y su condena del teatro, de las máscaras, de todas las formas de la representación en general, es decir, de la distancia de sí con los otros. Más aún, es uno de los sentidos que Foucault descubre en la relación que nuestra modernidad occidental mantiene con su propia sexualidad (Foucault, 1977). Y él se pregunta: ¿Por qué y cómo fue que llegamos a interesarnos tanto en la sexualidad, a ponerla en discurso como nunca se había hecho, a conectar sobre ella todos los proyectores del poder y a ver allí la identidad y la verdad decisiva de cada uno? Y él responde: fue el resultado de un largo proceso de confesiones, de desahogos, de investigaciones seudocientíficas, de preocupaciones biopolíticas que han hecho del hombre occidental no tanto un animal reprimido y púdico, sino un animal profundamente indiscreto.

Pero es mucho más claro aún, y de forma mucho más radical, el sentido del ataque frontal que realiza Lévi-Strauss al final del tercer volumen de las Mitológicas, oponiéndole a la moral occidental centrada en el sujeto ("ese insoportable niño mimado de la filosofía" como lo llamará más tarde) "una moral inmanente a los mitos amerindios" que se podía definir como una moral de la discreción. En efecto, no es un azar si ese volumen termina con la palabra "discreción". De forma más decisiva, Lévi-Strauss (1970) escribe esto en magníficas líneas: 
Pues nos han acostumbrado desde la infancia a temer la impureza del afuera. Cuando proclaman, por el contrario, que "el infierno es uno mismo», los pueblos salvajes dan una lección de modestia que desearíamos creer que aún somos capaces de oír. En este siglo en que el hombre se encarniza en la destrucción de innumerables formas vivientes, después de tantas sociedades cuya riqueza y diversidad constituían desde tiempo inmemorial lo más claro de su patrimonio, jamás sin duda ha sido tan necesario decir, como lo hacen los mitos, que un humanismo bien ordenado no comienza por uno mismo sino que coloca el mundo antes que la vida, la vida antes que el hombre, el respeto a los demás antes que el amor propio; y que incluso una permanencia de uno o dos millones de años sobre esta tierra, en vista de que de todas maneras tendrá fin, no podría servir de excusa a ninguna especie, así fuese la nuestra, para apropiársela como una cosa y conducirse hacia ella sin pudor ni discreción. (pp. 443-444)

Tendremos, entonces, que precisar cómo se piensa en la "filosofía de los salvajes" una tal moral inmemorial de la discreción. Lévi-Strauss (1970) la llama una "deferencia con respecto al mundo" que consiste en prohibirse ciertos usos y algunas prácticas, no porque ellos constituyeran "peligros para sí", sino porque constituían "peligros para los otros". Y, además, escribe él: "las buenas maneras sirven, entre los salvajes, para proteger la pureza de los seres y de las cosas contra la impureza del sujeto" (Lévi-Strauss, 1970).

Un grupo de mitos amazónicos resume ejemplarmente un tal propósito. Se trata de mitos que narran el viaje en piragua de la Luna y del Sol. Todo lo que pone en juego consiste, en efecto, en contar cómo el mundo solo puede funcionar gracias a una buena distancia encontrada entre la Luna y el Sol. Si se está demasiado próximo de la Luna, tendremos un "mundo podrido", mundo del silencio, de la oscuridad, de la humedad, de lo demasiado crudo; pero si estamos demasiado cercanos del Sol, el mundo se "quemaría", mundo de la baraúnda, de la luz enceguecedora, de la sequedad, de lo demasiado cocido. De ahí la necesidad para el Sol y la Luna de viajar sin fin en piragua, a buena distancia el uno de la otra. Ahora bien, en un viaje tal todos los sentidos de la discreción parecen condensarse: la Luna y el Sol, el uno en la proa y la otra en la popa, están en posiciones disimétricas que les impiden verse cara a cara (discreción visual); no deben hacer demasiado ruido para no espantar a los peces (discreción auditiva) y no deben remover porque pueden zozobrar (discreción gestual). La discreción no está simplemente exigida en determinados momentos o con ciertas relaciones particulares, no es una obligación moral específica... es más: ella es la moral misma.

Podríamos incluso ir un poco más lejos y añadir aún otros dos sentidos. Primero, ese mito del viaje de la Luna y el Sol llena ejemplarmente la función que Lévi-Strauss le confiere a la mitología en general, a la vez contra el ritual y contra la novela; trata de restaurar los "grandes intervalos" entre las parejas 
de opuestos que constituyen nuestra relación con el mundo (entre lo crudo o lo cocido, la noche y el día, lo cercano y lo lejano, el bullicio y el silencio, etc.), por tanto, asegura una separación simbólica allí donde el ritual y la novela tienen que ver más bien, por el contrario, con los pequeños intervalos, tratando de esa manera "desesperadamente", dice Lévi-Strauss, de salvaguardar la "continuidad de lo vivido" (Lévi-Strauss, 1976, p. 609). Dicho de otro modo, por una parte, el etnólogo preserva así el sentido matemático de la discreción, es decir, lo discontinuo; la moral de la discreción es la moral de un universo discreto dominado por la noción de distancia. Por otra parte, y más aún, nos recuerda que incluso si la discreción se elabora en gestos imperceptibles y miradas furtivas, su sentido no puede captarse sino en los grandes mitos (o las grandes metafísicas) y no en los rituales, infinitamente complicados e infinitamente obligantes, por los cuales los pueblos y las religiones han tratado de asimilarlos. Por el momento digamos que esta es una lección preciosa que no podemos olvidar luego.

Segundo, se encuentra aún un quinto sentido a la discreción: el de la ciclicidad o de la alternancia. Si la Luna y el Sol están, en efecto, consagrados a viajar sin fin en torno al mundo, eso implica que la ley de la discreción no consiste en aprender a desaparecer de repente y sin más, a negarse integralmente uno mismo en provecho de los otros o del mundo, sino aprender a desaparecer lentamente y a reaparecer lentamente, siguiendo una alternancia regulada; no es tanto el signo de un odio por sí mismo y de un "aprender a morir", como el signo de un amor por el mundo y de una participación en la vida eterna de sus ciclos infinitos.

Por todas estas razones, Lévi-Strauss, el roussoniano, nos parece más decisivo que Nietzsche y Foucault. Pero sobre todo es más radical, su lección nos lleva mucho más lejos. Pues si Nietzsche critica la indiscreción moderna es porque tiene nostalgia de los griegos, de un mundo de máscaras y de apariencias que desaparecen. Como Foucault (1984), aunque este tuvo que conceder en el Uso de los placeres que habiendo ido a buscar entre los griegos "pensar de otra manera" se encontró en "la vertical de él mismo". Ahora bien, ¿es seguro que los griegos hayan pensado verdaderamente la discreción? Lo que da a entender Lévi-Strauss es, más bien, que casi toda la civilización occidental, hasta en sus raíces antiguas, ha estado demasiado preocupada del sujeto como para poder captar el sentido de una "verdadera deferencia con el mundo"; por esto tenemos necesidad de aprender la lección de los "salvajes" de América, de África o de Asia. En este sentido, no podríamos encontrar la justa comprensión de la discreción allá donde un espíritu occidental tendría espontáneamente tendencia de ir a buscarla, en las éticas de los filósofos griegos o en las reglas de buena educación de las sociedades de corte medieval o clásica; que es esto lo que requerimos mostrar. 


\section{Pudor y prudencia de los antiguos}

En un primer análisis, cuando uno ya no soporta el "circo perpetuo de adulación para un estallido de vanidad", como dice Nietzsche, y particularmente todo ese exhibidor de fenómenos económico, político, mediático... que poluciona nuestra cotidianidad, uno tiende a dirigirse hacia las morales griegas. Ellas nos han legado, en particular, dos formas aparentes y simétricas de discreción para resistir a un tal sifón. Por un lado, la sabiduría epicúrea que puede resumirse en un único imperativo de Epicuro: "Oculta tu vida". Significa que debes practicar la exchorésis, el retiro por fuera de los asuntos de la ciudad y de la agitación común; enciérrate en tu jardín para entregarte a placeres simples y naturales con algunos amigos escogidos; rechaza la ostentación lujosa y la gloria de lo vulgar. Por el otro lado, se dispone de la sabiduría estoica que puede resumirse, en lo concerniente a la discreción, en el imperativo de Epicteto: practica la apatheia, es decir, la indiferencia con respecto a todo lo que no depende de ti y en particular todos los "falsos bienes de este mundo" (el placer sensual, los honores y el dinero). Aparentemente es otra manera de ser discreto. No se trata de retirarse suavemente a la soledad o con la compañía escogida, sino de vivir intocado y amurallado en medio de lo vulgar; y ahí "desempeñar su trabajo y hacer su oficio", ya se sea esclavo o emperador, puesto que la naturaleza lo decidió así, pero sin estarse identificando; por el contrario, refugiarse sin cesar en su "ciudadela interior" como dice Marco Aurelio, es decir, en el lugar de sus representaciones, que ellas dependan de sí y sobre las cuales uno pueda libremente decidir su tenor; o también aceptar participar en la tragicomedia del mundo social como un buen actor, a la manera de Séneca, ocultando su verdadera naturaleza a los ojos de todos.

Estas dos formas de retiro por fuera de las miradas del otro, ya sea en su jardín o en sí mismo - moral de actor, por un lado, moral de solitario por el otro-, son como el anverso y el reverso de una misma moral que poco, muy poco, tiene que ver con lo que se entiende por discreción, por lo menos por tres razones. Primero, porque esta moral reposa exclusivamente en un egoísmo bien comprendido; es por su felicidad propia que el epicúreo debe huir del lujo y la gloria encerrándose en su jardín; como es por su propia felicidad -igualarse a un dios, dice Séneca- que el estoico se hace "ciudadano del mundo" o "se conforma con la naturaleza". En verdad no hay en esto ninguna deferencia con el mundo, ningún deseo de dejarle lugar a los otros, solamente el deseo de ahorrarse su atestamiento... como ahorrarse la locura que sería, para el epicúreo, preocuparse por un mundo contingente, condenado por adelantado a la ruina; o no tener que vivir la locura que consistiría, para el estoico, en querer cambiar las cosas oponiéndose a la necesidad natural. Es, por el contrario, plenos de sí mismos que tanto el uno como el otro se retiran lejos de las miradas de los otros. 
En esto reside la segunda razón: mientras que la discreción es la experiencia del goce paradójico de retirarse uno mismo, de hacerse invisible, de desaparecer momentáneamente para abandonarse a la aparición del otro, de cesar por un instante de ser uno mismo, tanto el epicureísmo como el estoicismo solo prometen una presencia de sí más enaltecida y más plena. No son filosofías de la desaparición de sí, sino de su aparición superior; tanto el jardín de Epicuro como la ciudadela de Marco Aurelio son lugares radicalmente indiscretos, enteramente transparentes, sin secreto y sin misterio. Tercero, porque apoyándose en un egoísmo bien comprendido y la esperanza de una vida transparente de sí a sí mismo, tales morales movilizan en verdad otras virtudes distintas a la discreción: el pudor y la prudencia políticas.

Se podría comprender mejor este último punto si nos remontamos más atrás de las sabidurías helenísticas, hacia las filosofías de Platón y de Aristóteles. Dos términos ocupan el lugar que podría designar lo que se entendería por discreción: por una parte, el aidôs, que traducimos por pudor, modestia, reserva y hasta por vergüenza, es decir, la pena por haberse conducido mal en público; por otra parte, la phronésis, que se traduce por prudencia, justa medida, sagacidad o sabiduría práctica, y que designa, especialmente en Aristóteles, la disposición para determinar el "justo medio" en acciones inciertas (en este sentido es casi el todo de la virtud práctica). Pero si miramos con más detenimiento, es forzoso constatar que aidôs y phronésis denotan experiencias que son casi lo opuesto de la que hoy llamamos discreción.

Si seguimos en efecto el mito de Protágoras que expone Platón a comienzos del diálogo epónimo (320c-322d), el aidôs sería un don de Zeus para asegurar la salvaguarda de la humanidad (Platón, 1966) ${ }^{5}$. Más precisamente, el mito cuenta esto: en el origen, Epimeteo y Prometeo están encargados por los dioses de distribuir equitativamente entre todos los seres vivos las diferentes capacidades (a unos la fuerza sin la velocidad, a otros la velocidad sin la fuerza y así sucesivamente...); pero Epimeteo olvidó al hombre que quedó entonces "desnudo, sin zapatos, sin vestido, sin armas". Para salvarlo, Prometeo le robó entonces el fuego a los dioses y se lo ofreció a los hombres; pero esto no fue suficiente para darles bastante seguridad en la lucha por la supervivencia de quien vive con las bestias feroces. Zeus interviene y les regala, vía Hermes, "el saber político" constituido por dos virtudes simétricas: el aidôs, es decir, la ley política en tanto que ella es seguida, y la dikè, es decir, la ley en tanto que ella es prescrita; ordenándoles que maten a cualquiera que derogue estas dos virtudes.

Ver en lo posible la muy aclaradora introducción de Protagoras de la traductora al francés, Frederica Ildefonse y su anexo II, "sobre aidôs \& dikè" (Platón, 1998). 
Ahora bien, es difícil encontrar algún elemento que en este mito se parezca a la discreción. El aidôs sería un arma para asegurar su salvación, por no decir su supremacía, en una lucha encarnizada por la sobrevivencia. ¿Acaso la discreción no es, por el contrario, lo propio de las almas un tanto cansadas de una lucha tal y que desean retirarse del juego al menos por un momento? El aidôs sería como el reverso de la justicia, es decir, la facultad de sentir en sí mismo la regla común que se aplica a todos (regla de coraje, de solidaridad, de temperancia, etc.). ¿No reposa la discreción, por el contrario, en la consciencia de que no puede haber regla común desde el punto de vista del aparecer, que es preciso que algunos se retiren para que otros se muestren, dispuestos a intercambiar regularmente los roles? Más aún, ¿no indica la experiencia que es bueno de vez en cuando salir de la justicia y de las categorías del juicio, que es bueno tener momentos donde uno pueda eximirse de la regla común, así como es bueno dejarle al otro zonas de secreto donde no se llegará ni a mirar ni a juzgar? El aidôs aparece aquí como una virtud casi exclusivamente política, que vale como manifestación de su pertenencia a la comunidad. ¿No es la discreción, por el contrario, lo propio de las "comunidades de los que no tienen comunidad", como decía Blanchot en la Comunidad inconfesable? Más aún, ¿no es la discreción la postura que se adopta prioritariamente cuando se vive en un orden político en el que no se quiere participar, en particular en los Estados totalitarios? En fin, existe todo ese pathos de la amenaza de muerte enunciada contra todo el infractor putativo del aidôs que no conviene del todo; por el contrario, salvo en las dictaduras más monstruosas, nunca se ha ejecutado a nadie por su indiscreción. Todo el tiempo se han contentado con zarandearlo más o menos gentilmente, pedirle que se calle o que no se meta en lo que no le importa.

Esta distancia entre el aidôs de los griegos clásicos y lo que se entiende en la actualidad por discreción está aún más claro en otros textos. Por ejemplo, en el Eutifrón, Sócrates define el aidôs como una parte del temor (Platón, 1966b). Aristóteles (1987), en la Ética a Nicómaco, la define como "una especie de miedo a que se formen una mala opinión de sí"; y un poco antes precisa porqué no es una virtud, una disposición (hexis), sino más bien una afección; y poco después va a decir precisamente que ella solo le conviene a la juventud a la que le tempera los errores y no a un hombre maduro y virtuoso que no comete malas acciones y, por tanto, no tiene porqué sentir vergüenza ${ }^{6}$. Ahora bien, a este nivel no debemos ni siquiera seguir hablando de distancia, sino más bien de franca oposición entre la experiencia griega del aidôs y la experiencia moderna de la discreción. En la actualidad, el discreto es el que no experimenta ni temor ni vergüenza porque precisamente se salió de la pasión de su imagen pública; es el que no siente el aidôs en el sentido de Aristóteles. Es por esto por lo que lo más común es una

Ver el muy corto y anexo capítulo de la Ética a Nicómaco que Aristóteles (1987) consagra al aidôs (y que Jules Tricot, el traductor francés traduce por "modestia"). 
experiencia que le conviene, aunque no siempre, a las personas que gozan de una cierta edad, ya dejándole un poco el lugar a la exuberancia de la juventud, a sus fuerzas ingenuas pero bellas, de afirmación de sí mismos.

Se podría decir otro tanto del concepto central de la ética aristotélica, la phronésis, la prudencia. Ciertamente, Aristóteles define la virtud como una "disposición para actuar, de manera deliberada, que consiste en una "medianidad" relativa a nosotros, la que se determina racionalmente y como la determinaría el hombre prudente" (Aristóteles, 1987, II, p. 6). En esta "medianidad" o justo medio, ¿no se reencontrará esa "moral de la buena distancia" que caracterizaría la discreción de los amerindios? Para nada. Porque precisamente esta "medianía" es "relativa en sí" y se debería incluso decir enteramente relativa a sí mismo; ella no es más que la búsqueda por tanteo entre dos imágenes viciosas de sí mismo (por ejemplo, la cobardía y la temeridad); ella no es de ninguna manera buena distancia con los otros y con las cosas, preocupación por el afuera. En este sentido, el phronimos, el prudente que determina la virtud en Aristóteles, podrá evidentemente producir acto de discreción en el sentido en que lo entendemos hoy, tal como el médico o el estratega que se cuidarán de intervenir y que permanecerán al asecho hasta que se presente el "momento oportuno" (kairós) para operar o para atacar. Pero lo hará por razones muy distintas a las que presenta el discreto de hoy: por cálculo, por interés, por precisión en la captación del momento oportuno, es decir, decisivo; mientras que el discreto actual hace de sus momentos de discreción momentos radicalmente inoportunos, es decir, sin decisión y sin pertinencia para el resto de su vida (ellos solo valen por ellos mismos), momentos en los que ya no calcula nada, se olvida todo interés propio, para solo dejarse abandonado en la suavidad de una vida liberada de la deliberación racional y activa. No se podría encontrar distancia más considerable; Aristóteles sitúa la modestia bien debajo de la sabiduría práctica que, a su vez, depende de una vida teorética o contemplativa más elevada (incluso termina por quedar en lo más bajo, puesto que no es ni siquiera una virtud práctica en tanto que tal). Mientras tanto, la filosofía moderna tendería, más bien, a situarla en la cima de la vida contemplativa.

Parece, por consiguiente, que los grandes textos de la filosofía antigua no ofrecen ningún espacio para pensar la discreción. Aparentemente hay dos razones opuestas, pero de hecho son la misma razón. En efecto, por un lado, en las filosofías helenísticas, es decir, en las filosofías del Imperio (alejandrino primero y luego romano), la discreción se hace apolitismo, salida completa del mundo (así sea bajo la forma de su aceptación incondicional) y refugio en sí mismo (así sea bajo la forma de un actor, vacía e impotente en el mundo), lo que es profundamente contrario a la experiencia de la discreción que es cuidado del mundo y de los otros. Por el otro lado, en la filosofía griega clásica de Platón y Aristóteles, el 
pudor y la prudencia solo son pensados de forma política, independientemente de toda preocupación moral por los otros y por el mundo, lo que también es contrario de la discreción. Pero, de hecho, en los clásicos y en los helenísticos, se trata quizás de la misma limitación: los filósofos griegos nunca pudieron concebir la menor dialéctica entre una moral privada, aunque política, y una política pública, aunque dejase lugar a formas de existencia privada. $\mathrm{O}$ ellos le concedieron todo a la cuestión de la salud de la comunidad pública, a la manera de Platón y de Aristóteles, o se dedicaron por entero a la cuestión de la salvación individual, a la manera de los epicúreos o de los estoicos; no supieron pensar ese entredós que constituye la discreción, a la vez virtud moral y subversión pública, a la vez retiro de la comunidad y salvaguarda del mundo.

Desde este punto de vista, lo verdadero, el puro filósofo griego es Diógenes. Es él el que dice la verdad de todos los otros, verdad que se llama parrhesía, es decir, "coraje de la verdad". Un coraje tal es, en efecto, la fortaleza de la indiscreción más radical, del impudor más provocador. Diógenes se masturbaba en la plaza pública, arrastraba tras él, con un cordel, un pescado podrido, vivía semidesnudo en un tonel y caminaba a mediodía con una linterna que decía "busco un hombre". Diógenes es la figura más ejemplar de la indiscreción filosófica. Y Foucault tiene toda la razón en recordar que, en un sentido, su fuerza no residió en producir nada original ni sofisticado, sino en haber resumido los fundamentos de los filósofos de su tiempo, haberlos condensado en el credo común más despojado y de haberlos escupido en la cara; la filosofía es la parrhesía, el "coraje de la verdad", la valentía de vomitar toda modestia, todo pudor, todo retiro, todo suspenso; es el coraje de no ocultar nada y de desnudarlo todo (Foucault, 2010). Evidentemente, es una figura admirable que explica por qué amamos tanto la filosofía griega, esa rabia de no concederle ni un ápice a la mentira a sí mismo, bien sea en el orden de la vida pública o en el de la vida privada. Pero también se comprende por qué no se le puede pedir que nos enseñe algo sobre la verdad de la discreción. No tiene que ver con que el alma discreta esté en la mentira de sí mismo, en arreglos consigo mismo y la mala fe que horrorizan a todos los filósofos griegos, sino porque ella ha superado esta obsesión; no es para nada su objeto, por tanto, no nos puede enseñar nada de su relación con el mundo y con los otros, que finalmente siempre son tan poca cosa.

Tenemos que proseguir nuestras averiguaciones en otro lado.

\section{La discreción, icualidad del hombre de corte?}

¿Si nuestra experiencia moderna de la discreción no nació en el suelo de la filosofía griega, en qué suelo nació? El sentido común dice: las gentes del pueblo hablan fuerte y mucho, viven en una terrible promiscuidad, se comportan sin pudor y sin genio, no saben ocultarse o volverse silenciosos, no saben ser un 
poco elegantes con los otros (las mujeres, los extranjeros, las minorías en general); las gentes discretas son los señores y fueron ellos los que inventaron la discreción. Si hay un poco de buenas costumbres, un poco de compostura y de cortesía en el pueblo hoy, es gracias al espíritu aristocrático que poco a poco diseminó sus formas de disciplina en la psiquis común. Pero el sentido común dice también lo contrario: la discreción es el pueblo que sabe callarse, que sabe ocupar su lugar, no quiere sino su parte bien lejos de los círculos corruptos del poder en los que solo se busca mostrarse, espiarse, hacerse notar del rey y de los poderosos. ¿Qué vamos a creer entonces?

En un sentido, toda la fuerza y la originalidad de la noción de "proceso de civilización" inventada por Norbert Elias (1987) consisten en mostrar que estas dos ideas del sentido común pueden conciliarse y no son necesariamente contradictorias. Su tesis es, en efecto, la siguiente. Un doble proceso de civilización comenzó en Francia y en Europa desde el siglo XII; consistió en pacificar y estabilizar las relaciones interhumanas a través de una doble dinámica: primero, la aparición, especialmente en las sociedades de corte, de nuevas normas sociales tendientes a extender las formas de la civilidad hasta las acciones más cotidianas (no charlar demasiado, no poner los codos en la mesa, no escupir ni sonarse en público, defecar en la intimidad y no hablar de ello, disimular sus relaciones sexuales, etc.), es decir, el progreso de la "civilización de las costumbres" o "civilización del comportamiento". Segundo, la extensión de esas normas al conjunto de la sociedad por un proceso de interiorización o de "superyoización" colectiva que consiste en reprimir "la economía pulsional espontánea" y elevar progresivamente el umbral del "pudor y la pena". En la sociedad de corte, Elías (1990) llama a ese proceso "curialización", es decir, en su sentido restringido, monopolización a la vez de la violencia legítima y de la fiscalidad por parte de un soberano único, que difunde en la nobleza de provincia las reglas de "buena educación" de la sociedad cortesana; y en su sentido amplio, extensión de tales reglas propias de las cortes al conjunto de la sociedad por medio de círculos concéntricos.

Si un proceso tal de civilización o de curialización se impone al hilo de los siglos en Europa, no aconteció porque los nobles fueran inicialmente "los más civilizados"; en un sentido, era incluso lo inverso, ellos estaban sumidos por completo en la economía afectiva del guerrero, hecha de brutalidad y de culto a la fuerza. La civilización del comportamiento es el fruto de una lucha feroz en el seno de clases dominantes desposeídas de su violencia inicial y, por tanto, obligadas a conducirse de otra manera para poder permanecer próximas al poder. Es por esto por lo que, al extenderse, el proceso de civilización no tiende a atenuarse, sino a reforzarse; por ejemplo, la burguesía media naciente en el siglo XVIII juzgará inmoral y cínico los tratados de cortesía o de urbanidad 
producidos por la aristocracia de los siglos precedentes (los de un Erasmo, un caballero de Méré o de un Baltasar Gracián). Es lógico pensar que, entre más uno se acerque a las formas de "corte" o actualmente a los "centros" del poder, más estamos llevados a encontrar formas de discreción extremadamente refinadas y formas de brutalidad y de indiscreción inesperada. El sentido común tiene razón en pensar una cosa y la otra.

Se le ha podido reprochar a Norbert Elias un irenismo ciego. ¿Cómo creer por un segundo en un proceso de civilización y de pacificación de las sociedades europeas luego de la violencia inaudita de la Primera Guerra Mundial (durante la que Elias fue severamente herido), y en el momento en que nacen los peligros de la Segunda Guerra Mundial (que obligaron a Elias a exiliarse)? Un tal reproche no nos parece enteramente fundamentado; Norbert Elias conocía demasiado bien a Freud como para no saber que un proceso de superyoización sin límite, y que se autorrefuerza, no podía cumplir la promesa de un final feliz. En desquite, nuestro problema tendrá que ver más con el hecho de que lo que el sociólogo alemán llama cortesía, pena, pudor, no tiene gran cosa que ver con la experiencia de la discreción que buscamos desde el comienzo. ¿Qué es la cortesía? Un proceso sin fin de distinción, un refinamiento en el arte de mostrarse y de picar las migajas del poder... lo contrario de la discreción. ¿Qué entiende Elias por "pudor"? "Una especie de miedo ante la degradación social o un gesto de superioridad que alguna otra persona podría hacer" (1990), es decir, casi que palabra a palabra la definición aristotélica del aidôs que, como lo hemos visto, es lo contrario de la discreción. ¿Qué entiende por "sentimientos de pena"? "Sentimientos displacenteros o temores que surgen cuando otra persona enfrenta o se apresta a enfrentar los tabúes representados por el Superyo" (Elias, 1987), es decir, muy exactamente los sentimientos de los que nos protege por adelantado la experiencia de la discreción. Y de manera más general, ¿qué es una "sociedad civilizada"? Una sociedad en la que los hombres "se han habituado a observarse recíprocamente", es decir, un universo radicalmente indiscreto.

No hemos logrado avanzar ni un paso en nuestra búsqueda de un suelo propio de la experiencia moderna de la discreción. Y lo podríamos mostrar tomando un solo ejemplo de los tratados de urbanidad que estudia Elias, el más célebre de todos: Oráculo manual y arte de prudencia de Baltasar Gracián (MDCLIX), que fue traducido al francés como L'Homme de cour, y que conoció infinidad de ediciones en los siglos XVII y XVIII ${ }^{7}$. En efecto, a primera vista este arte de la prudencia se da a leer como un puro arte de la discreción. "Saber abstraher, que, si es gran lición del vivir el saber negar, mayor será saberse negar a sí mesmo, a los negocios, a los personajes [sic]", previene él (§ 33); a primera vista

Para un primer abordaje de la obra de Gracián, ver la práctica y reciente edición Art et figures du succès. (Oracle manuel) de Gracián (2012). 
no podríamos encontrar ningún mandato más explícito a la discreción. Lo que él mismo llama "Arte de dexar estar. Y más quando más rebuelta la común mar, o la familiar. Ai torbellinos en el humano trato, tempestades de voluntad; entonces es cordura retirarse al seguro puerto del dar vado [sic]" (§ 138). Y dice además en (§ 123): "Nunca el Discreto se ha de dar por entendido de sus méritos, que el mismo descuido despierta en los otros la atención. Dos vezes es eminente el que encierra todas las perfecciones en sí, y ninguna en su estimación [sic]". Ahora bien, la afectación, es decir, el énfasis y la falta de naturalidad, es claramente el antónimo de la discreción: "no se ha de estar siempre de excepción; el ser singular en exceso, es condenar a los otros" aconseja sabiamente (§ 275). Evidentemente, se nota el "estar siempre de excepción" porque lo propio de la discreción es no condenar a los que quieren mostrarse bajo una luz favorable, sino solamente a los que se quieren mostrar todo el tiempo, comenzando por ellos mismos.

Se podrían multiplicar las lecturas de este género y se encontraría en Gracián, dispersos aquí o allá, prácticamente todos los rasgos de la experiencia de la discreción. ¿Pero se trata en él de una experiencia propiamente de discreción? Si es preciso "saberse alejar" es para "no gastar la preciosa decencia"; hay que saberse "poner al abrigo" para no ser salpicado, más por sabia prudencia que por auténtica discreción; si es menester desterrar toda afectación, es para preservar la benevolencia de todos a nuestro respecto; no es para amar, es para que nos amen; si se requieren "grandes secretos" es para "ocultar en ellos grandes designios"; y si hay que "retener su crédito" es para gozar más tarde del "usufructo del renombre". Las formas de discreción que describe Gracián no parecen tener ningún valor en sí mismas; no son sino medios al servicio de fines completamente distintos: la sumisión a la decencia, la preservación de su interés propio en caso de peligro, la satisfacción de tener éxito en el mundo. En verdad, la discreción de Gracián no tiene nada que ver con la discreción verdadera; no es sino un mixto de prudencia aristotélica y de astucia maquiavélica puesta al servicio de un puro arte de las apariencias. Y esto Gracián (MDCLIX) lo reconoce explícitamente en el aforismo 130: "Las cosas no passan por lo que son, sino por lo que parecen. Valer y saberlo mostrar es valer dos vezes. Lo que no se ve es como si no fuesse [sic]". No estamos seguros de que él se regocije de ello, pero es seguro que él toma nota del asunto y no imagina que exista una alternativa a esa constatación.

Tampoco es en el suelo de la mundanidad, como no lo fue en el suelo de la filosofía griega, que ha podido brotar las raíces de nuestra experiencia occidental de la discreción. ¿Pero entonces cuál fue su suelo? ¿Qué es lo que nos ha permitido, al menos a algunos de nosotros, vivir y pensar a veces como los "salvajes" de Lévi-Strauss? 


\section{Referencias}

Aristóteles. (1987). Ética a Nicómaco (trad. Jules Tricot). Vrin.

Baudelaire, C. (2010). Le Peintre de la vie moderne. Fayard/Mille et une nuits.

Didi-Huberman, G. (2015). Fasmas. Ensayos sobre la aparición 1. Shangrila Textos Aparte.

Elias, N. (1987). Sobre el proceso de civilización. Fondo de Cultura Económica.

Elias, N. (1990). La sociedad de los individuos. Península.

Foucault, M. (1977). Historia de la sexualidad I. La voluntad de saber. Siglo XXI.

Foucault, M. (1984). Historia de la sexualidad II. El uso de los placeres. Siglo XXI.

Foucault, M. (2010). El coraje de la verdad. Fondo de Cultura Económica.

Gracián, B. (MDCLIX). Oráculo manual y arte de prudencia. Ámsterdam: Ivan Blaev. https://play.google. $\mathrm{com} /$ books/reader?id=UfRIAAAAcAAJ\&hl=es\&pg = GBS.PA1

Gracián, B. (2012). Art et figures du succès. (Oracle manuel). Seuil.

Ildefonse, F. (2012). Il y a des dieux. PUF.

Kafka, F. (1995). Diarios (1910-1923). Tusquets.

Lévi-Strauss, C. (1970). Mitológicas III. El origen de las maneras de mesa. Siglo XXI.

Lévi-Strauss, C. (1976). Mitológicas IV: el Hombre Desnudo. Siglo XXI.

Nietzsche, F. (s.f.). Sobre verdad y mentira en sentido extramoral. Biblioteca Virtual Gratuita (One More Library). https://onemorelibrary.com/index.php/es/?option=com_djclassifieds\&format =raw\&vie $\mathrm{w}=$ download\&task $=$ download\&fid $=3272$

Platón. (1966). Protágoras o los sofistas. Aguilar.

Platón. (1966b). Eutifrón, o de la piedad. Aguilar.

Platón. (1998). Protagoras (trad. Federica Ildefonse). Flammarion.

Proust, M. (1954). À la recherche du temps perdu. À l'ombre des jeunes filles en fleurs. Gallimard.

Rancière, J. (2014). El reparto de lo sensible. Prometeo.

Spinoza, B. (1980). Ética. Editora Nacional.

Zaoui, P. (2013). La discrétion: Ou liart de disparaître (pp. 9-68). Editions Autrement. 